\title{
MIR376A1 wt Allele
}

National Cancer Institute

\section{Source}

National Cancer Institute. MIR376A1 wt Allele. NCI Thesaurus. Code C82193.

The human MIR376A1 wild-type allele is located in the vicinity of $14 q 32.31$ and is approximately 67 bases in length. This allele, which encodes MIR376A1 pre-miRNA, plays a role in the regulation of gene expression. Alteration in the expression of this gene is associated with epithelial ovarian cancer. 